than $\$ 400,000$; 10 more received at least $\$ 300,000$ in salary, fees, bonuses, and benefits; 67 were paid between $\$ 200,000$ and $\$ 300,000$; and the total salary and benefits for 62 others was between $\$ 175,000$ and $\$ 200,000$.

Across the country, administrative salaries have for years been higher than faculty salaries, and it is taken for granted that this is as it should be. In the last two decades the inequality has grown significantly. The consequence of this conjuncture is, among other things, an even steeper decline in the proportion of academic budgets available for rewarding efforts in teaching.

There are two obvious explanations for the striking growth of administrative salaries. First, some would contend that administrative salaries are market driven-that the skills necessary for staff work in colleges and universities, leadership ability for example, are truly out of the ordinary. There is a seller's market for academic administrators and their uncommon talents. They are in great demand. Any number of institutions of higher learning are eagerly waiting to recruit them. This external labor market for academic administrators drives up their salaries.

Although this interpretation may sound reasonable, it is not supported by fact. Indeed, research shows that the labor market forces that affect the salaries of academic administrators are relatively weak. There is not much of an external labor market competing for academic administrators. The majority spend their entire career in one or two institutions. It is rare for them to find positions at an institution with more prestige than the one at which they are located. About half move into their positions from within the same institution.

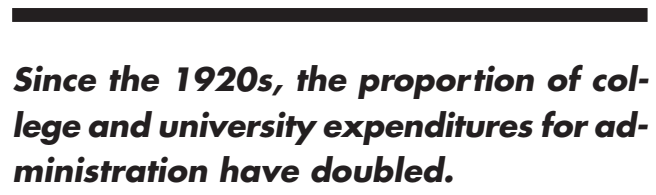

In light of the disproportionate share of economic resources taken by them, it would not be unfair to fault academic administrators, at least in some part, for the situation in American colleges and universities with regard to teaching. The claim is heard that they are sympathetic about the putative imbalance in the reward structure in higher education. However, not only have they done little to address it, but their excessive claims on limited resources have clearly exacerbated the situation. It thus seems self-evident that the more spent on administration, the less that can be spent on things other than administration.

This article is an abbreviated version of chapter 10, Marginal Worth: Teaching and the Academic Labor Market (New Brunswick, NJ: Transaction Publishers, 1996).

\section{A Coming Student Revolution?}

\author{
Philip G. Altbach \\ Philip G. Altbach is Monan professor of higher education and director \\ of the Center for International Higher Education at Boston College.
}

$\mathrm{I}_{\mathrm{t}}^{\mathrm{t}}$ is time to consider the impact on students of the various academic crises affecting higher education worldwide. The student political activism of the 1960s is but a dim memory now, but the fact is that students can and do still react, sometimes violently, to campus change and deteriorating conditions. There are indications that students may again take to activism, adding an important dimension to the academic equation. It is surprising that students have been so quiet worldwide as campus conditions deteriorate. There are signs that students are again becoming a force to be reckoned with.

The most dramatic example of student reaction now is in Germany, where the largest student demonstrations since the 1960s have taken place in the past few months to protest the rapidly deteriorating conditions in German universities. Massive demonstrations in Berlin, Frankfurt, and other cities have involved thousands of students in protests against budget cuts, overcrowding in the universities, and the general neglect of the universities by German authorities, who have been focused on economic problems and the challenges of reunification. It is widely recognized that the universities have suffered dramatically in recent years. They have been forced to absorb major increases in student numbers without added resources. This has led to overcrowding. Students now take seven or more years to finish their first degrees. Some are even choosing to study in other countries, such as the Netherlands, where academic conditions are better.

After suffering silently for almost a decade, the current wave of demonstrations has forced governmental authorities to take notice. So far, the only reaction has been finger-pointing by federal and state authorities.

In France, students over the past decade have taken to the streets to protest against educational reforms aimed at rationalizing the French university system and making student funding income related. Students succeeded in halting the reform, and French politicians, regardless of party, are reluctant to propose any new changes in current policy for fear of arousing student opposition.

It is somewhat surprising that students in other European countries have not taken to the streets. Throughout Europe, universities have experienced a combination of increased enrollments and stagnant or decreased funding. Italy has been especially hard-pressed, and the conditions of teaching and learning in Italian universities are among the worst in Western Europe. British higher education has been profoundly restructured in recent years. Margaret Thatcher's Conservatives totally reorganized the system, creating new universities by upgrading the polytechnics to university sta- 
tus. Patterns of funding were changed as well. Students in both sectors were affected. The new Labour government of Tony Blair announced the imposition of tuition fees beginning this year. For the first time, British students will have to pay significant fees for their studies, although the amounts will be well below what American students in public universities pay. Student organizations in Britain have strongly opposed the imposition of fees, and there have been a few demonstrations, but no serious unrest as yet.

The current wave of demonstrations has forced governmental authorities to take notice. So far, the only reaction has been finger-pointing.

The student activism of the 1960s was stimulated at first by campus issues in the United States and in Europe. Students reacted to what Europeans call the "massification" of higher education. In the United States, one slogan was "do not fold, spindle, or mutilate" - a reference to the computer punch cards of the time. This was a plea not to be treated as mere statistics in an academic system that was growing rapidly. European students also reacted to dramatic expansion and deteriorating conditions on campus. It is no coincidence that the French student revolt, which came close to toppling the government of Charles deGaulle, started on the campus at Nanterre, a particularly dreary and overcrowded new branch of the University of Paris.

Campus conditions are today deteriorating in Europe as a result of government policy rather than of severe economic crisis or mismanagement by university administrators. Just as in the 1960s, expansion is not being combined with increased funding. Morale throughout academe is low, and it is the students who are increasingly discontented. Student anger has boiled over in Germany, and it is at least possible that other countries will follow.

A long period of campus quiet has lulled policymakers into discounting students as a potential political and social force. Students are directly affected by government policy concerning higher education. They must pay the tuition fees now being imposed in Britain, study in overcrowded lecture halls, and tolerate inadequate libraries and laboratories in much of Europe. Students have so far accepted their fate. Now, their patience seems to be running out.

Policymakers and administrators ignore student views at their peril. Once mobilized, students can be a powerful force. The 1960s taught us that student political activism is difficult to predict and that it rises from unanticipated causes. Whether the recent German demonstrations are a precursor to wider unrest is not yet known.

\section{Britain's Quality Support Centre}

\section{John Brennan}

John Brennan is head of the Quality Support Centre at The Open University. Address: The Open University, 344-354 Gray's Inn Road, London WC1X 8BP, UK. Telephone: + 44 (0)171 2784411 . Fax: + 44 (0)171 837 0290. E-mail: <qsc@open.ac.uk>. Website: <http:// www.open.ac.uk/OU/Admin/QSC.html>.

The Quality Support Centre (QSC), part of Britain's Open University, is a center for higher education research and information. It specializes in two principal research areas: (1) systems and methods of quality assessment, assurance, and evaluation; and (2) issues of quality arising from the relationship between higher education and the world of work. A large part of QSC's activities are international. In 1997, QSC was engaged in the following international projects:

- quality management, quality assessment, and the decisionmaking process - a study of the impact of quality assessment on higher education institutions in 15 OECD countries;

- quality assurance in higher education in Central and Eastern Europe- - a project to develop higher education quality assurance systems in 11 countries in Central and Eastern Europe;

- accreditation of higher education in Bulgaria-a project to support the creation of a National Evaluation and Accreditation Agency; and

- higher education and graduate employment in Europepart of a nine-country study of the employment experiences of graduates.

Within Britain, QSC has recently completed projects on work-based learning and the impact of quality assessment upon institutions. It is currently involved with a project on key skills development through work-based learning. Although many of QSC's activities are practical and developmental, they all lead to published reports. Some of these are published by QSC itself, and its Higher Education Reports series includes papers by international scholars, as well as QSC staff members.

QSC also publishes a regular information bulletin, the Higher Education Digest. The Digest contains around 40 brief information items on recent higher education developments. Items are grouped under general headings such as quality assurance; teaching, learning and assessment; policy and funding; curriculum development; higher education and work; recent statistics; and the contents of recent higher education journals. Although the emphasis is on developments within a British context, many of the items in each issue concern, or would be relevant to, higher education in other countries. The Higher Education Digest is available by subscription only and is published three times per year.

QSC also runs conferences and workshops, nationally and internationally. As a self-financing organization, its staff are available for consultancy and collaborative projects with higher education institutions and agencies all over the world. 